\title{
Polityczno-etniczny aspekt kształtowania się wschodnich granic Republiki Białorusi w latach 1918-1924
}

Zarys treści: W artykule omówiono historyczny kontekst problemów granicznych Białorusi w latach 1918-1924. Skoncentrowano się głównie na źródłach archiwalnych opisujących debaty wewnątrz partii, które uwarunkowywały zmiany na mapie politycznej. Temat taki podjęto, gdyż w polskojęzycznej literaturze problematyka wymiany ziem między Białorusią a Rosją w latach dwudziestych XX w. została opisana w sposób ogólny, lekceważąc obecnie dostępne źródła i bez uwzględnienia czynników o charakterze etnicznym.

Outline of content: The article discusses the historical context of Belarusian border problems in 1918-1924. Emphasis is put on the archival source materials describing debates within the communist party, which conditioned changes on the political map of Europe. The subject has been brought up also because the problems of a land exchange between Belarus and Russia in the 1920s are usually presented in Polish historiography in a general way, with disregard to available sources and ethnic factors.

Słowa kluczowe: Republika Białorusi, historia, granice, ZSRR

Keywords: Republic of Belarus, history, borders, USSR

\section{Wprowadzenie}

Zakończenie I wojny światowej stało się punktem kulminacyjnym w długotrwałym procesie walki europejskich narodów o prawo do samostanowienia. Bezsensowne krwawe starcia na frontach Wielkiej Wojny spowodowały wzmocnienie ruchów emancypacyjnych. Narody pragnęły pokoju. Jednak państwa biorące udział w światowym konflikcie ignorowały podobne dążenia własnych społeczeństw. Po obu stronach nasilały się tendencje, które wkrótce doprowadziły do upadku 
czterech imperiów i uzyskania niepodległości przez wiele nowych podmiotów politycznych.

1 sierpnia 1917 r. Benedykt XV wydał notę pokojową skierowaną do walczących państw. Wzywał w niej do zawarcia pokoju bez zwycięzców i zwyciężonych. Apelował do stron konfliktu o pokój oparty na poszanowaniu praw narodów. Nieco później, 22 stycznia $1917 \mathrm{r}$. Thomas Woodrow Wilson wygłosił przed Kongresem mowę o „pokoju bez zwycięstwa”, opierającym się na równości narodów i poszanowaniu praw ludów do samostanowienia.

Hasła bolszewików, którzy o wiele wcześniej niż Woodrow Wilson czy Benedykt XV zaczęli mówić o pokoju bez zwycięzców i zwyciężonych oraz wyzwoleniu narodów spod jarzma imperiów, trafiły na Wschodzie na podatny grunt. W Imperium Rosyjskim, jako pierwszym wśród państw walczących, doszło do rewolucji. Jednak obalenie caratu, a później i rządu tymczasowego nie przyniosło kompromisu dla licznych ludów zamieszkujących tereny Imperium Rosyjskiego, lecz przeciwnie - konflikt rozgorzał na nowo. Starcia między różnymi ośrodkami siły trwały jeszcze przez kilka lat.

Republika Białorusi stanowi przykład państwa, które pod wieloma względami może być uznane za twór sztuczny. Kształt granic kraju został narzucony z góry przez komunistów, którzy podporządkowali go swoim potrzebom, często z pominięciem czynników narodowościowych czy kulturowych. Dyskusje, które miały miejsce we frakcji bolszewickiej Socjaldemokratycznej Partii Robotniczej Rosji na początku XX w. i dotyczyły kwestii białoruskiej, polegały na tym, że wcześniej, jako odrębny polityczny podmiot, Białoruś nie istniała, w wyniku czego dyskutowano o obszarze podlegającym pod bezpośrednią jurysdykcję Mińska. Co więcej, etnogeneza Białorusinów jako narodu o własnej tożsamości skończyła się dopiero w pierwszej połowie XX w. ${ }^{1}$, do czego w znacznej mierze przyczyniło się uzyskanie suwerenności w ramach Związku Radzieckiego. Aktualnie w białoruskiej historiografii zauważalne są próby zakorzenienia własnej państwowości w starodawnych dziejach, jednak ma to charakter nienaukowy.

Jako zasadniczy cel niniejszego artykułu wybrano analizę dokumentów, które zostały wytworzone przez biurokratyczny aparat terytorialnych jednostek komunistycznej partii zachodnich guberni Rosyjskiej Federacyjnej Socjalistycznej Republiki

\footnotetext{
${ }^{1}$ Początek oraz pierwsza połowa XX w. są najczęściej wskazywane przez historyków jako czas uzyskania przez Białorusinów własnej tożsamości. Samo wyodrębnienie Białorusinów jako grupy etnicznej nadal stanowi temat debat. Przykładowo Gieorgij Sztychow i Michaił Tkaczow uważają, że już w XIII w. Białorusini byli odrębnym etnosem, natomiast w XVII w. rozpoczął się proces kształtowania się narodu białoruskiego. Mojżesz Grinbłat uznaje, że jako grupa etniczna Białorusini zaczęli wyróżniać się wśród innych narodów dopiero w XIV-XVI w. Polscy badacze tradycyjnie zajmują nieco inne stanowisko w tej kwestii. Więcej na ten temat zob. Г.В. Штыхов, Археолагі дапаўняюиь тетапісиаў, Мінск 2009; М.Я. Гринблат, Белорусы. Очерки происхождения и этнической истории, Москва 1968; P. Wróbel, Kształtowanie się białoruskiej świadomości narodowej a Polska, Warszawa 1990; R. Radzik, Między zbiorowościa etniczna a wspólnota narodowa. Białorusini na tle przemian narodowych w Europie Środkowo-Wschodniej XIX stulecia, Lublin 2000.
} 
Radzieckiej (RFSRR) w trakcie pracy nad administracyjnym powiększeniem terytorium Białoruskiej Socjalistycznej Republiki Radzieckiej (BSRR). Zakładana hipoteza mówi o decydującej roli politycznego faktora $\mathrm{w}$ analizowanym procesie. Warto podkreślić, że Białoruś stanowi jeden z nielicznych przypadków dobrze udokumentowanego procesu tworzenia podmiotu o suwerenności państwowej w Europie XX w., gdyż biurokratyczny aparat Związku Radzieckiego pozostawił wiele źródeł. Przedmiot badania jest tym istotniejszy, że łączy wiedzę z zakresu zarówno historii, jak i politologii. Podstawę artykułu stanowią obecnie udostępniane źródła archiwalne. Ponadto zostały wykorzystane następujące zbiory dokumentów i materiałów: wydane w Mińsku w 2012 r. Государственные границы Беларуси. Сборник документов и материалов в двух томах (Państwowe granice Białorusi. Zbiór dokumentów i materiałów w dwóch tomach) oraz opublikowana w Mińsku w 1999 r. Знешняя палітыка Беларусі. Зборнік дакументау і матэрыялаў. т. 2: 1923-1927 22. (Zewnętrzna polityka Białorusi. Zbiór dokumentów i materiałów, t. 2: 1923-1927).

Przyjęta cezura potrzebuje krótkiego wyjaśnienia. Temat kształtowania się granic Republiki Białorusi jest tak szeroki, że trudno go przedstawić w jednym artykule. Zatem ze względów formalnych w poniższym tekście zdecydowano się skupić na badaniu jedynie pierwszego powiększenia terytorium BSRR. Było ono najbardziej istotne. Ponadto oba (w 1924 r., a później w 1926 r.) procesy powiększenia terenu Białorusi odbywały się w identyczny sposób.

Zagadnienie kształtowania się wschodnich granic BSRR w okresie od jej powstania do 1924 r. w nieznacznym stopniu zostało już opracowane w literaturze białorusko- i rosyjskojęzycznej, gdyż główną uwagę rosyjskojęzycznych historyków przykuwała kwestia ustanowienia zachodniej granicy ZSRR. Tę tematykę przedstawiali m.in.: Jurij Borisionok, Siergiej Chomicz, Rygor Łaźko². W polskiej literaturze temat ten też jest podejmowany, aczkolwiek przeważnie przyczynkarsko. Główna uwaga polskich historyków skupia się na kwestii Kresów Wschodnich, pozostawiając niezbadanym proces polityczno-terytorialnych zmian odbywających się na Wschodzie. W publicystyce problem ten głównie przedstawiony jest w skrajnie prawicowej rosyjskojęzycznej prasie. W podobnych tekstach pod znakiem zapytania stawia się niepodległość Białorusi, uznając ją za teren oderwany

2 Zob. np.: Ю.А. Борисёнок, Белорусско-российское пограничье в 1918-1944 годах, „Вопросы истории" (2004), № 12, s. 105-112; О.В. Требов, Как большевики делили гомельскую губернию между Россией и Белоруссией, „Родина” (2003), № 8; У. Ладысеў, П. Брыгадзін, Паміж Усходам i Захадам. Станаўленне дзяржаўнасиі і тэрытарыяльнай целаснасиі Беларусі (1917-1939), Мінск 2003; Р.Р. Лазько, А.М. Кротаў, М.М. Мязга, Беларусь у еурапейскай палітыцы, 19181925 г2. Нарысы, Гомель 2003; С. Хомич, Территория и государственные границы Беларуси в ХХ веке. От незавершенной этнической самоидентификаиии и внешнеполитического произвола к современному status quо, Минск 2011; А.В. Ціхаміраў, Беларусь у сістэме міжнародных адносін перыяду пасляваеннага ўладкавання Еўропы і польска-савецкай вайны (1918-192122.), Мінск 2003. 
od Rosji. Podobne rozważania trudno uznać za naukowe, gdyż ukazują podejście propagandowe, podporządkowujące faktologię ideologii. Dlatego też w niniejszym artykule zdecydowano się zająć względnie nieporuszanym tematem, którego główne nowatorstwo stanowi sama koncepcja zapoznania się z dotychczas nieopracowanymi przez nierosyjskojęzycznych naukowców źródłami.

\section{Narodzenie BSRR}

Decyzja o utworzeniu Republiki Białorusi (jako republiki radzieckiej) została podjęta przez Komitet Centralny Rosyjskiej Partii Komunistycznej (bolszewików) [KC RPK(b)] w grudniu 1918 r. Stanowiła ona kontynuację komunistycznych haseł o szanowaniu prawa ludów do samostanowienia. Nie ulega wątpliwości, że w powstającym państwie robotników i chłopów prawo do suwerenności posiadały jedynie podmioty ogłaszające gotowość dołączenia się do proletariackiej rewolucji. Elita partii komunistycznej uznała, że akt nadania suwerenności Białorusi (tak jak Ukrainie) stanie się najlepszym sposobem promowania ideologii komunistycznej w Europie. Do przyjęcia danej decyzji przyczyniło się także to, że już w 1918 r., przy aktywnym wsparciu niemieckich władz okupacyjnych ${ }^{3}$, powstały quasi-państwowe $e^{4}$ organizacje obejmujące tereny Ober-Ost, w tym zamieszkiwane przez Białorusinów ${ }^{5}$. Podobne procesy kierownictwo partii uznawało za zagrożenie, ponieważ mógł ujawnić się kolejny „burżuazyjny” wróg, tym razem w postaci Białorusi. W rzeczywistości projekt Białoruskiej Republiki Ludowej (BRL) od

\footnotetext{
${ }^{3}$ W trakcie I wojny światowej w wyniku pokonania armii Imperium Rosyjskiego w 1915 r. znaczna część terenów zamieszkanych przez Białorusinów znalazła się pod okupacją państw centralnych, które aktywnie prowadziły własną politykę po podporządkowaniu zajętych ziem. Więcej na temat administracyjnej organizacji okupowanych terenów zob. В.В. Волкава, Адміністрацыйнатэрытарыяльнае ўладкаванне акупаванай тэрыторыі Беларусі у гады Першай сусветнай вайны (кастрычнік 1915 г. - люты 1918 г.), „Беларускі Гістарычны Часопіс” (2017), № 10, s. 32-44; еаdет, Пашпартная сістэма зоны Обер Ост у гады Першай сусветнай вайны, „Беларускі гістарычны часопіс” (2015), № 3, s. 22-29.

${ }^{4}$ Za jedną z takich organizacji może być uznana BRL z następujących powodów: jej nietrwałości, braku aparatu biurokratycznego oraz niejasnego śladu, który pozostawiła ona w historii. Kwestia tego, czy była ona przejawem okupacyjnej polityki Rzeszy Niemieckiej, czy pierwszym niepodległym państwem białoruskim, znajduje się poza ramami niniejszego artykułu. Aczkolwiek trzeba zaznaczyć, że oficjalna historyczna szkoła Białorusi określa BRL mianem „niemieckiego protektoratu”. Więcej na temat przyczyn niepowodzenia projektu BRL zob. D. Michaluk, Białoruska Republika Ludowa między Wschodem a Zachodem (1918-1919), „Studia Białorutenistyczne” 3 (2009), s. 63-101; А.В. Ціхаміраў, op. cit.

5 Traktat brzeski oznaczał utratę przez Rosję zachodnich terenów znajdujących się w niemieckiej strefie okupacyjnej, m.in. obwodów, w których Białorusini stanowili większość mieszkańców. Jednak już traktat wersalski uznawał pokój brzeski wraz ze wszystkimi dodatkami za niebyły. Więcej na temat Białorusi w okresie I wojny światowej zob. В.Н. Белявина, Беларусь в годы Первой мировой войны, Минск 2013; V. Kipel, Z. Kipel, Byelorussian Statehood. Reader and Bibliography, Michigan 1988.
} 
samego początku był skazany na porażkę, gdyż stanowiła ona jedynie „papierową republikę", która nie zyskała uznania na arenie międzynarodowej ${ }^{6}$. Niemniej jednak ogłoszenie powstania BRL wywarło wpływ na politykę bolszewików na terenach zamieszkanych przez Białorusinów.

1 stycznia 1919 r. Tymczasowy Robotniczo-Chłopski Radziecki Rząd Białorusi, znajdujący się w Smoleńsku, ogłosił powstanie Socjalistycznej Radzieckiej Republiki Białorusi (SRRB) ${ }^{7}$. Nowa związkowa republika została utworzona na terytorium istniejącego wcześniej Zachodniego Obwodu Rosji ${ }^{8}$. W skład nowo powstałego państwa weszły niegdysiejsze gubernie Imperium Rosyjskiego: grodzieńska, mińska, witebska, mohylewska, smoleńska i niektóre ujezdy do niej przylegające ${ }^{9}$. Warto zaznaczyć, że w rzeczywistości większość tych terenów - zwłaszcza na zachodzie - nie była kontrolowana ani przez rząd w Moskwie, ani przez partyjne struktury w Mińsku. W taki sposób utworzono kraj bezpośrednio graniczący na zachodzie z Polską i obejmujący władzą część etnicznych polskich ziem, na których Polacy stanowili znaczny odsetek mieszkańców (np. na Grodzieńszczyźnie i w niektórych zachodnich ujezdach guberni mińskiej oraz witebskiej) ${ }^{10}$. Dostępne obecnie źródła archiwalne wskazują na to, że wbrew oczekiwaniom przewodniczących partii komunistycznej podjęta decyzja spotkała się ze sprzeciwem funkcjonariuszy z terenów podporządkowanych nowej republice. Wyjątek stanowili działacze z mińskiego oddziału partii komunistycznej, natomiast reszta terytorialnych organizacji wyraziła zdecydowany sprzeciw. Podobny protest został przedstawiony w poniższym fragmencie deklaracji Witebskiego Komitetu Rosyjskiej Partii Komunistycznej:

Rosyjska Partia Komunistyczna (bolszewików) jest zwolennikiem prawa do samostanowienia ludów, nawet jeżeli to wiąże się z podziałem. Jednocześnie $\mathrm{z}$ tym nie dążymy do rozdrobnienia sił proletariatu poprzez stworzenie nowych krajów oraz nowych granic

${ }^{6}$ Więcej na temat BRL i jej wpływu na tożsamość Białorusinów zob. D. Michaluk, Białoruska Republika Ludowa 1918-1920. U podstaw białoruskiej państwowości, Toruń 2010; D.R. Marples, Belarus. A Denationalized Nation, Abingdon 1999; T. Snyder, The Reconstruction of Nations. Poland, Ukraine, Lithuania, Belarus, 1569-1999, Oxford 2003.

7 У.Ф. Ладысеў, П.І. Брыгадзін, op. cit., s. 102.

8 Zachodni Obwód Rosji - administracyjna jednostka ze stolicą w Smoleńsku, która powstała w wyniku terytorialnej reformy przeprowadzonej przez rząd Republiki Rosyjskiej w 1917 r.

9 Kształt granic Białorusi został utwierdzony w trakcie posiedzenia I Zjazdu Komunistycznej Partii (bolszewików) Białorusi. Постановление Комитета Витебской Организации РКП(б) по вопросу об образовании Белорусской Республики от 16 января 1919 г., w: Государственные гранищы Беларуси. Сборник документов и материалов в двух томах, т. 1, Минск 2012, s. 78-79.

${ }^{10}$ Kwestia polskości tych ziem nadal jest przedmiotem licznych sporów, gdyż polskojęzyczna literatura przedmiotu prezentuje nastawienie odmienne od rosyjskojęzycznej. Zob. P. Wróbel, op. cit.; E. Mironowicz, S. Tokć, R. Radzik, Zmiana struktury narodowościowej na pograniczu polsko-białoruskim w XX wieku, Białystok 2005; S. Ciesielski, Kresy Wschodnie II Rzeczypospolitej i problemy identyfikacji narodowej, w: Przemiany narodowościowe na Kresach Wschodnich II Rzeczypospolitej, red. S. Ciesielski, Toruń 2003, s. 9-51. 
państwowych, lecz do ścisłej współpracy na podstawie proletariackiej spójności, aby pokonać każdą próbę osłabiania siły proletariatu. Rewolucyjna walka wymaga możliwie jak największej centralizacji państwowego aparatu dyktatury proletariatu. Wszelkiego rodzaju aspiracje „zwolenników niezależności” osłabiają zdolność do walki i przeszkadzają celom proletariatu, bowiem sprzyjają fałszywym nacjonalistycznym interesom.

W odniesieniu do konkretnego przypadku - utworzenia Republiki Białoruś - nie jest on uzasadniony żadnymi przesłankami. Kraj dawno poddał się rusyfikacji, dlatego też nie ma w nim nic narodowego: ani języka, ani kultury. Szerokie proletariackie i chłopskie masy Białorusi nic nie łączy z białoruską świadomością.

Komitet sugeruje, że ogłoszenie niepodległości Białorusi obudzi w narodowych masach aspiracje, których później będzie bardzo trudno się pozbyć, co więcej, spowolni to postęp w rozwoju socjalizmu.

$\mathrm{Na}$ arenie międzynarodowej akt zostanie wykorzystany przez międzynarodowych imperialistów w celach niekorzystnych dla rosyjskiego proletariatu.

Postrzegamy ten akt jako przedsięwzięcie zakażonych nacjonalizmem towarzyszy z białoruskiego komisariatu. Witebski Komitet Komunistycznej Partii Rosyjskiej (bolszewików) deklaruje, że proletariackie i chłopskie masy Białorusi dążą do jedności z resztą radzieckiej Rosji i sprzeciwiają się ogłoszeniu „niepodległości”11.

Aktywny protest przeciwników utworzenia Republiki Białorusi zmusił Moskwę do wycofania się z planów obdarowania Białorusinów suwerennością. Tym bardziej że już 16 stycznia 1919 r. KC RPK(b) przyjął decyzję wchłonięcia przez RFSRR (czyli Rosję) obwodów witebskiego, mohylewskiego oraz smoleńskiego ${ }^{12}$. Natomiast na podstawie jednostek administracyjnych guberni mińskiej, grodzieńskiej, wileńskiej oraz kowieńskiej stworzono Litewsko-Białoruską Socjalistyczną Republikę Rad (Litbieł). Do zmiany zamierzeń doszło z powodu braku powodzenia w wojnie polsko-bolszewickiej. Zakładano, że Litbieł stanie się buforowym państwem, które mogłoby zostać łatwo oddane II Rzeczypospolitej Polskiej w przypadku porażki w rozgrywającym się konflikcie, natomiast przekazane Rosji obwody byłyby później wykorzystane do odbudowy Białorusi ${ }^{13}$.

Ponownie do ogłoszenia suwerenności Republiki Białorusi doszło 31 lipca 1920 r. w Mińsku ${ }^{14}$. Wtedy kształt granic znów się zmienił, gdyż zdecydowano,

11 Постановление Комитета Витебской Организации РКП(б) по вопросу об образовании Белорусской Республики от 16 января 1919 г., w: Государственные границы беларуси..., т. 1 , s. $78-79$.

12 Proces zmiany administracyjnej jest opisany m.in. w sprawozdaniach organów centralnej władzy. Zob. nр.: Из приказа НКВД РСФСР о передаче восьми волостей оршанского уезда гомельской губернии в состав витебской и смоленской губерний, w: Административно-территориальное устройство БССР: справочник. В 2-х томах, т. 1: 1917-1941 г2., Минск 1985, s. $30-31$.

13 Koncepcja ta została udokumentowana w raporcie z posiedzenia CB KР(b)B 22 stycznia 1919 r., протокол заседания ЦБ КП(б)Б по вопросам территории республики и федеративных отношений с РСФСР, w: Государственные границы беларуси..., т. 1, s. 82-85.

14 Декларация о провозглашению независимости Советской Социалистической Республики Беларусь, w: ibidem, т. 1, s. 120-121. 
że będzie opierał się na zasadzie etnicznej, która nie miała nic wspólnego z administracyjnym podziałem z czasów Imperium Rosyjskiego.

Socjalistyczna Radziecka Republika Białorusi określa swoją zachodnią granicę na podstawie etnograficznej granicy między Białorusią a okolicznymi państwami burżuazyjnymi. Granica Socjalistycznej Radzieckiej Republiki Białorusi z Rosją i Ukrainą zdeterminowana zostanie przez wykaz woli narodu białoruskiego w trakcie powiatowych i wojewódzkich zjazdów sowietów na podstawie serdecznego porozumienia z rządami RFSRR i USRR ${ }^{15}$.

Aczkolwiek do samego rozejmu z Polską 18 marca 1921 r. rząd nowo powstałej republiki nie kontrolował własnego terytorium ${ }^{16}$. Co więcej, w wyniku traktatu pokojowego pozbawił się on większości ziem należnych mu de iure, które zostały przyłączone do II Rzeczypospolitej Polskiej. W rękach Mińska pozostało tylko sześć powiatów obwodu mińskiego (miński, borysowski, bobrujski, ihumeński, mozyrski i słucki). Jako że republika w takich granicach nie odpowiadała ani gospodarczym, ani militarnym zapotrzebowaniom bolszewików, zaczęto opracowywać plany stawiające na powiększenie administracyjnych jednostek na zachodzie Rosji przez wcielenie do nich obwodów radzieckiej Białorusi. Wskutek wdrożenia w życie takiego rozwiązania Białoruś zostałaby podporządkowana planowanemu Zachodniemu Obwodowi. Jednak sowiecka elita wybrała inną opcję, w wyniku czego Białoruś stała się jedną z czterech założycielskich republik ZSRR.

Warto zaznaczyć, że po rewolucji październikowej w partii bolszewików toczyła się dyskusja na temat organizacji państwa oraz prawa narodów, w tym Białorusinów, do samostanowienia. Wydzielono trzy podstawowe nurty. Stronnicy państwa unitarnego dążyli do utworzenia republiki rad niepodzielonej na państwa narodowe. Już w 1917 r. Gieorgij Piatakow w trakcie posiedzenia pietrogradskiego sowietu stwierdził, że „prawo narodów do samostanowienia jest głupotą"17. Nie zostało to jednak poparte przez większość komunistów, gdyż wielu z nich reprezentowało mniejszości narodowe Imperium Rosyjskiego. $Z$ tego też względu nurt ten powinien być uznany za margines głównej debaty ${ }^{18}$. Drugi nurt stanowili zwolennicy Stalina, którzy nawoływali do utworzenia autonomii dla mniejszości narodowych w ramach RFSRR. W rezultacie takiego rozwiązania nowo powstała federacja radziecka w znacznej mierze przypominałaby obecną Federację Rosyjską. Koncepcja ta cieszyła się znaczącym poparciem komunistów z rosyjskiego oraz białoruskiego ${ }^{19}$ oddziału partii komunistycznej. Trzecie rozwiązanie problemu było rozpracowywane

15 Ibidem.

16 Zob. J. Borzęcki, The Soviet-Polish Peace of 1921 and the Creation of Interwar Europe, New Haven 2008.

17 Седьмая (Апрельская) Всероссийская конференция РСДРП(б). Стенографический отчет, Москва 1958, s. 211-212.

18 А. Басалай, Развитие наций и их взаимоотношений в СССР, Москва 1998, s. 106-107.

19 Całość zbadanych źródeł wskazuje na dominację tej koncepcji wśród białoruskich funkcjonariuszy. 
przez Lenina - właśnie na tych założeniach został utworzony w $1921 \mathrm{r}$. ZSRR. W ramach tego nurtu zdecydowano się na obdarowanie „odrębnych” narodów własną państwowością. Wśród beneficjentów polityki znalazła się m.in. Białoruś ${ }^{20}$.

\section{Kwestia „powiększenia” Białorusi}

Przenoszenie jurysdykcji nad administracyjnymi jednostkami między poszczególnymi republikami w ramach ZSRR odbywało się regularnie. Przykład tego stanowią: powiększenie obwodu orenburskiego o część ziem należących do Kazachstanu w 1934 r., przekazanie okręgu taganroskiego w 1925 r. z Ukraińskiej Socjalistycznej Republiki Radzieckiej (USRR) do RFSRR, podporządkowanie Republiki Krymu Kijowowi w 1954 r. itd. Podobna sytuacja miała również miejsce w przypadku wschodniej Białorusi i jest znana w historiografii pod nazwą "powiększenie BSRR” (ros. Укрупнение Беларуси). Za czasów Związku Radzickiego podobne sytuacje miały charakter wyłącznie administracyjny, gdyż musiały doprowadzać do usprawnienia struktury władzy. Natomiast po odzyskaniu niepodległości przez poszczególne republiki w niektórych przypadkach stało się to źródłem międzypaństwowych konfliktów ${ }^{21}$.

Kwestia zmiany kształtu wschodnich granic radzieckiej Białorusi była podnoszona przez część białoruskich komunistów już od momentu uzyskania niepodległości. Funkcjonariusze KC białoruskiego oddziału partii apelowali do Lenina w sprawie zwiększenia terenu administracyjnie podporządkowanego Mińskowi. Twierdzono m.in., że dołączenie nowych obszarów do republiki zamieni Białoruś we wzorcowy kraj komunistyczny zachęcający zagraniczny proletariat do kontynuowania walki z burżuazją. W celu przekonania najwyższego szczebla władzy komunistycznej białoruscy funkcjonariusze zwrócili się do ekonomistów, którzy opracowali koncepcje „samowystarczalnej suwerenności”. Zgodnie z planem zwiększenie terytorium oraz stworzenie bazy przemysłowej na Białorusi powinny napędzić jej rozwój i polepszyć warunki życia zamieszkujących ją osób, co z kolei spowodowałoby intensyfikację narodowowyzwoleńczych ruchów Białorusinów mieszkających w II RP. Podobne cele określono w części przebadanych dokumentów. Na przykład w raporcie CB Komunistycznej Partii (bolszewików) Białorusi [KP(b)B] skierowanym do KC wskazano następujący problem: „[Białoruś] w jej obecnych granicach nie może być wystarczająco atrakcyjnym centrum dla Białorusinów, którzy mieszkają na zachodzie"22.

${ }^{20} \mathrm{Na}$ taki charakter wskazuje raport sporządzony przez KC KP(b)B, Narodowe Archiwum Republiki Białorusi, Национальный архив Республики Беларусь (dalej: НАРБ), Ф. 4-п, Оп. 1, Д. 1247, Л. 1-7.

21 Przykładowo: aneksja Krymu, separatystyczne ruchy Azerbejdżanu, terytorialne pretensje Estonii do Rosji.

22 НАРБ, Ф. 4-п, Оп. 1, Д. 1247, Л. 1-7. 
Właściwie na tym etapie nastąpił końcowy podział poglądów komunistycznych działaczy Białorusi. Część zajęła pozycję pronarodową, domagając się od Moskwy zwierzchnictwa nad całym obszarem zamieszkanym przez osoby uznające siebie za Białorusinów. Część zaś dążyła do zjednoczenia z Rosją, które spowodowałoby pozbawienie Białorusi suwerenności. Oficjalny rząd BSRR stał po stronie „narodowościowej”, natomiast Moskwa zajęła pozycję wyczekiwania, gdyż miała liczne problemy związane $\mathrm{z}$ chłopskimi buntami oraz toczącymi się na południu i wschodzie konfliktami.

Już we wrześniu 1922 r. Ludowy Komisariat Spraw Zagranicznych radzieckiej Białorusi zwrócił się do centralnych władz ZSRR z prośbą o konieczne porozumienie w sprawie wschodniej granicy: „uznaję potrzebę rozwiązania kwestii wschodnich granic Republiki Białorusi przez dołączenie do republiki obwodów: homelskiego, witebskiego i części smoleńskiego"23. Prośba ta została uargumentowana przez mińskich teoretyków marksizmu, którzy przekonywali centralny aparat partii komunistycznej do zgody na tę propozycję. Po pierwsze, odnotowano ważność jednego systemu sprawowania władzy w regionie, bowiem podział administracyjny pogarsza jakość życia obywateli.

Terytorium BSRR oraz Homelszczyzna, Witebszczyzna i część Smoleńszczyzny stanowią jedność pod naturalnymi, etnograficznymi i gospodarczymi względami. Teren ten odróżnia się od sąsiednich, a zatem wymaga wspólnego gospodarczego planu i kierownictwa, które wzięłoby pod uwagę cechy charakterystyczne dla tegoż regionu i zapewniłoby minimalny poziom dobrobytu w zjednoczonej w taki sposób republice ${ }^{24}$.

Po drugie, zwrócono się ku czynnikom demograficznym oraz narodowościowym, bowiem na terenie tym uznano przewagę elementu białoruskiego. „Gubernie: witebska, homelska i częściowo smoleńska pod względem populacji stanowią kontynuację BSRR, gdyż są zamieszkane tym samym plemieniem co Radziecka Republika Białoruś. Około $82 \%$ populacji na tym obszarze posługuje się językiem białoruskim i posiada białoruską tożsamość narodową"25. Po trzecie, ujawniono zewnątrzpolityczne zamiary Komunistycznej Partii Białorusi (KPB) dołączenia do republiki ziem zamieszkanych przez Białorusinów na zachodzie.

Dlatego że Białoruś stanie się pełnoprawnym państwem równym Litwie, Łotwie czy Polsce, będzie to centrum przyciągnięcia dla zagranicznych Białorusinów. Ta część białoruskiego społeczeństwa, która nie wspiera radzieckiego rządu z przyczyn politycznych, widząc, że Białoruska Republika Radziecka rośnie w siłę i nie istnieje alternatywa dla białoruskiej państwowości, przyłączy się do ruchu na rzecz dołączenia znajdujących się pod polską okupacją historycznych ziem Białorusi ${ }^{26}$.

${ }^{23}$ Ibidem, Д. 2479, Л. 61-64, Копия.

${ }^{24}$ Ibidem.

25 Ibidem.

${ }^{26}$ Ibidem. 
Jak można zauważyć na przykładzie zacytowanego fragmentu tekstu, w partyjnej elicie Białorusi aspiracje do poszerzenia terytorium na zachód cieszyły się wsparciem części funkcjonariuszy.

Jednocześnie oficjalną notą, uzasadnianą sięgnięciem do problematyki politycznej (utworzeniem z Białorusi nowego centrum siły, gotowego do poszerzenia na zachód, na podstawie jej wzmocnienia dzięki wcześniejszemu powiększeniu na wschodzie), KC KPB rozpoczął kampanię w celu przekonania społeczeństwa do realności zagrożenia rusyfikacją. „Wcześniej i nawet teraz w guberniach witebskiej i homelskiej nie pozwalają na organizację białoruskich szkół mimo białoruskiej większości na wsi. $Z$ tego powodu rośnie niezadowolenie i tworzy się podatny grunt dla wszelkiego rodzaju demagogicznych i często prawdziwych oskarżeń wobec Rosjan o szowinizm i nacjonalizm" ${ }^{27}$. Podobne zarzuty spotkały się ze sprzeciwem partyjnych organizacji Witebska i Homla, które nie chciały zgodzić się na dołączenie do radzieckiej Białorusi, woląc pozostać częścią radzieckiej Rosji.

Między innymi w trakcie toczących się sporów zwracano się ku narodowej świadomości Białorusinów. Komuniści mińskiego oddziału, zajmujący stanowisko nacjonalistyczne, wskazywali na budzenie się świadomości Białorusinów, natomiast funkcjonariusze wtedy zachodnich obwodów Rosji zapewniali centralny rząd o braku zgody mieszkańców na zmianę podziału administracyjnego. Obie opcje odnosiły się do czynników politycznych, gdyż ostateczna decyzja musiała zapaść w Moskwie. Mimo to posługiwano się środkami masowego przekazu, będącymi w dyspozycji partii, w celu przekonania jak największej liczby mieszkańców do poprawności własnej wizji przyszłości rzekomych terenów ${ }^{28}$. Wyniki powszechnych spisów także wykorzystywano w rozgrywającym się sporze ${ }^{29}$. Homelski gubernialny komitet sporządził dla KC Komunistycznej Partii Rosji (KPR) własną opinię, która przekonywała o konieczności jak najszybszego zlikwidowania Białorusi z jednoczesnym dołączeniem jej terenów do Rosji.

Powszechny Spis Ludności 1920 roku wykazał ogólny spadek odsetka osób pochodzenia białoruskiego w homelskiej guberni, czym położył kres legendzie o „białoruskich powiatach” [...]. Jeżeli zaś od narodowościowego podziału powrócić do kwestii dobrobytu oraz narodowej świadomości, wtedy zrozumiemy, że mamy do czynienia ze zjawiskiem braku narodowej tożsamości Białorusinów. Zauważalne jest wrogie nastawienie mieszkańców do przeprowadzanej w języku białoruskim kampanii oświeceniowej. Co więcej, zdarza

27 Докладная записка ЦБ КП (б) Б в ЦК РКП (б) по вопросу о территории БССР от апрель 1923 г., w: Государственные гранииы беларуси..., т. 1, s. 191-194.

${ }^{28}$ Konflikt między dwoma nurtami został opisany w liście kierownika komisji Centralnego Wykonawczego Komitetu ZSRR Awiela Jenukidze, Письмо председателя комиссии ЦИК СССР по изменению границ между РСФСР и БССР А.С. Енукидзе в политбюро ЦК РКП(б) о разногласиях между членами комиссии 19 декабря 1923 г., w: ibidem.

${ }^{29} \mathrm{Na}$ intensywność debat wskazują protokoły z posiedzeń samorządów oraz partyjnych organizacji, НАРБ, Ф. 4-п, Оп. 1, Д. 683, Л. 10-14, Копия. 
się, że ludność zamieszkanych przeważnie przez Białorusinów okręgów aktywnie przeciwstawia się przekształceniu rosyjskojęzycznych szkół w białoruskojęzyczne ${ }^{30}$.

Jak każde źródło, które zostało stworzone w państwie autorytarnym, ujawniony powyżej fragment raportu pozostawia miejsce dla rozważenia kwestii o własnej wiarygodności. Niemniej jednak w prosty sposób wskazuje on na brak szerokiego wsparcia koncepcji suwerenizacji Białorusi przez naród. Podobna rzeczywistość, w ramach paradygmatu komunistycznego, mogła zostać rozwiązana na dwa sposoby: po pierwsze, na podstawie intensyfikacji polityki „białorusizacji” wybranych obszarów $\mathrm{z}$ jednoczesnym dołączeniem ich do Białorusi ${ }^{31}$, a po drugie, $\mathrm{w}$ ramach kontynuacji dotychczasowej carskiej polityki rusyfikacji. Oba podejścia można uznać za polityczne $\mathrm{z}$ natury, gdyż dominują $\mathrm{w}$ nich czynniki w żaden sposób niezwiązane $\mathrm{z}$ ewolucyjnym charakterem etnogenezy.

Najlepszym dowodem na fakt konieczności rychłego rozwiązania kwestii granic radzieckiej Białorusi w latach dwudziestych jest raport sporządzony przez witebski komitet gubernialny, ujawniający rozpowszechnienie w świadomości społeczeństwa wtedy zachodnich obwodów Rosji nastrojów niepewności. Zostały one poddane badaniom w ramach ankiet oraz wywiadów dotyczących nastawienia do koncepcji „białorusizacji” różnych warstw wspólnoty: komunistów o pochodzeniu białoruskim, białoruskiej inteligencji, ludności chłopskiej. Najważniejsze fragmenty odnoszące się do analizowanej kwestii umieszczono poniżej.

Badanie opinii funkcjonariuszy komunistycznych o pochodzeniu białoruskim ujawniło ich sprzeciw wobec pomysłu wchłonięcia witebskiego i homelskiego regionu przez Białoruś. „W autonomicznych republikach i regionach na wschodzie musimy liczyć się z nacjonalistycznymi nastrojami wśród komunistów. Natomiast w naszej republice białoruscy komuniści są zagorzałymi przeciwnikami «białorusyfikacji» obwodu. [...] Negatywne nastawienie do języka białoruskiego jest dominujące nawet wśród komunistycznych funkcjonariuszy na wsi" ${ }^{32}$.

W trakcie posiedzenia gorodoksijej rady miejskiej wygłoszona została następująca opinia: „Chociaż chłopi nazywają siebie Białorusinami, to jednak nie rozumieją oni języka podniosłego. Natomiast miejscowa ludność wykazuje zdolność do rozumienia języka rosyjskiego, którym posługiwano się w biurach oraz szkołach"33. Między innymi zostało to potwierdzone przez innego występującego - towarzysza

30 Из доклада гомельского губкома в ЦК РКП(б) по докладу ЦБ КП(б)б о расширении границ БССР от 4 октября 1923 г., w: Государственные границы беларуси..., т. 1, s. 197-200.

31 Polityka taka miała miejsce w latach dwudziestych XX w. Zob. У.К. Коршук, Р.П. Платонаў, І.Ф. Раманоўскі, Я.С. Фалей, Беларусізацыя. 1920-я гады. Дакументы і матэрыялы, Мінск 2001; H. Głogowska, Białoruś 1914-1929. Kultura pod presja polityki, Białystok 1996.

32 НАРБ, Ф. 4-п, Оп. 1, Д. 1247, Л. 66-73, Копия, Из докладной записки Витебского Губкома РКП(б) по белорусскому вопросу после 8 декабря 1923 г. Skrócona wersja tego dokumentu została umieszczona także w Государственные границы Беларуси... т. 1, s. 214-225.

33 Ibidem. 
Zarieckiego: „Sięgnę po przykład: w ubiegłym roku był tu PSZCZIELKO, który rozmawiał z chłopami i ludnością miejską w języku białoruskim. Prawie nikt go nie zrozumiał" 34 . W rezultacie stwierdzono, że narodowa tożsamość Białorusinów $\mathrm{w}$ tamtejszym powiecie nie ma miejsca, więc nie istnieje zapotrzebowanie na białoruskojęzyczne szkoły. Łatwo zauważyć, że działacze komunistyczni kwestionowali nie tylko prawo do istnienia Białorusinów jako odrębnego narodu, lecz stawiali pod znakiem zapytania suwerenność radzieckiej Białorusi, uznając teren ten za integralną część Rosji.

W przypadku inteligencji źródła wskazują na zajmowanie przez nią stanowiska probiałoruskiego. Jednak aspiracje do wprowadzenia do edukacji języka białoruskiego spotykały się ze sprzeciwem prorosyjskich funkcjonariuszy: „Wśród nauczycieli białoruskiego pochodzenia istnieją dążenia nacjonalistyczne"35. Zostały one wyraźnie przedstawione na spotkaniu pracowników szkół w Witebsku przez Suchorukowa i Wasilewskiego:

Jedynie „atrybut językowy” nie jest wystarczający, aby sądzić, że Witebsk nie należy do Białorusi. Nie istnieje jedyny język białoruski. Język ten jest podzielony na kilka dialektów, które najbardziej zauważalne są na wschodzie i na południu. Etnograficznie, historycznie i ekonomicznie Białoruś ma przesłanki, aby się odrodzić, a nawet „powstać”. Białoruś posiada wszystko dla zapewnienia własnego rozwoju i dobrobytu [...] białoruska kultura znajdowała się w upadku, zaś teraz mamy do czynienia z odrodzeniem naszej kultury [...] (Sukhorukow) $)^{36}$.

Wasilewski wskazał, że szkoły powinny mieć charakter dopasowany do kultury obszaru. Język białoruski jako macierzysty winien odgrywać ogromną rolę w szkole. Aczkolwiek zdecydowana większość oratorów wypowiadała się przeciw zmianom w edukacji: „ «Nasz» Białorusin z Witebska nie zrozumie języka białoruskiego. Nie jest on mu potrzebny”37; „Do Moskwy, nie do Mińska pragnie chłop. Sami chłopi nie lubią języka białoruskiego" ${ }^{38}$. Przedstawiony fragment raportu ujawnia podział, który został odnotowany przez funkcjonariuszy partii komunistycznej wśród inteligencji. Z tego dokumentu wynika, że członkowie partii komunistycznej Witebska oraz Homla nie byli przychylnie nastawieni do kwestii rozszerzania Białorusi, dlatego zignorowali głosy sprzeciwu społeczności i zdecydowali się kontynuować dotychczasową politykę (wsparcie rusyfikacji), jednocześnie narzucając ją inteligencji.

Na posiedzeniu została przyjęta uchwała: „Białoruski problem w naszym powiecie nie istnieje. Wśród ludności nie ma dążenia do oddzielenia się od rosyjskiej kultury; rosyjski szowinizm nie jest zauważalny, lecz przeciwnie, wprowadzenie

\footnotetext{
34 Ibidem.

${ }^{35}$ Ibidem.

${ }^{36}$ Ibidem.

37 Ibidem.

38 Ibidem.
} 
języka białoruskiego do szkół i instytucji rządowych stałoby się rodzajem opresji narodowej, gdyż ludność nie zna języka białoruskiego" ${ }^{39}$. W wątku tym widać sprzeciw wobec przedstawionych $\mathrm{w}$ niniejszym raporcie opinii nauczycieli, co pozwala zasugerować częściową niewiarygodność danego dokumentu, sporządzonego jedynie w celu politycznym.

Ostatnia część analizowanego raportu opisuje nastroje chłopów zamieszkujących tereny o spornej przynależności:

W trakcie prywatnych rozmów z chłopami wykazują oni prawdziwe zdziwienie faktem postanowienia podobnej decyzji. Ogólnie rzecz biorąc, zauważalne jest to, iż kiedy białoruskim chłopom czytają gazety w języku białoruskim, wtedy starzy ludzie je rozumieją. Natomiast młodzież twierdzi, że nie może zrozumieć tego języka. Najostrzejszą postawę przeciwko językowi białoruskiemu wyraża młodzież; osoby starsze w danej kwestii czasami wyrażają się we współczujący sposób ${ }^{40}$.

Reszta dokumentu stanowczo potwierdza ten sam nastrój wśród szerokich mas chłopskich. Chłopi zostali wskazani jako naturalny przeciwnik nadania Białorusinom suwerenności. Osoby, które sporządzały ten raport, zasugerowały, że świadomość Białorusinów polega na uznaniu ludu białoruskiego za część narodu rosyjskiego.

Zebranie stwierdza, że chociaż mieszkańcy guberni witebskiej są uznawani za Białorusinów, jednak od dawna stracili oni własną tożsamość, w wyniku czego język białoruski stał się dla nich językiem obcym. Wśród ludności nie istnieje potrzeby przyłączenia do Białorusi; urządzenie białoruskojęzycznych szkół i wprowadzenie języka białoruskiego w rządowych instytucjach doprowadzi do stworzenia reżimu opresyjnego, dlatego też wyrażają sprzeciw wobec pomysłu przyłączenia się do BSRR ${ }^{41}$.

Mimo to sporządzony raport zakwestionował poprawność spisu ludności od 1920 r. Głównym przedmiotem rozważań stała się kwestia narodowościowa, gdyż zgodnie ze spisem Białorusini stanowili 56,95\% populacji obwodu, zaś Rosjanie $32,58 \%{ }^{42}$. Podobny podział został określony kłamliwym, stworzonym na korzyść „towarzyszów zarażonych nacjonalizmem”, czyli funkcjonariuszy z już stworzonego oddziału KPB. Oprócz tego w raporcie wskazano na bardzo niski poziom świadomości Białorusinów, którzy nie utożsamiali się z żadnym państwem bądź strukturą organizacyjną. KC zasugerowano ustawienie granic pomiędzy Białorusią a Rosją na zasadzie podziału językowego, gdyż był on dla Rosjan o wiele korzystniejszy

39 Ibidem.

40 Ibidem.

41 Ibidem.

42 Niestety, w trakcie kwerendy nie udało się odnaleźć danych spisu ludności z 1920 r. w odniesieniu do terenu Republiki Białorusi, więc jedyne źródło wskazujące na tę statystykę to tekst „Из докладной записки Витебского...” 
niż etniczny ${ }^{43}$. 79,4\% mieszkańców wskazanego terenu posługiwało się językiem rosyjskim jako ojczystym, natomiast język białoruski był ojczysty jedynie dla 17,4\%. Należy zaznaczyć, że radzieckie spisy ludności z badanego okresu trudno uznać za źródło wiarygodnych informacji. Co więcej, sytuacja językowa, ze względu na brak jasnej tożsamości Białorusinów i istnienie odrębnych gwar, była bardzo skomplikowana; chłopi nie zawsze potrafili określić, jakim właściwie językiem się posługują. Jednak dyskusja nad kwestią językową nie należy do tematyki poruszonej w niniejszym artykule.

Poziom napięcia $\mathrm{w}$ wewnątrzorganizacyjnej debacie pokazuje poniższy cytat, w którym przedstawiciele Gubernskiego Komitetu guberni witebskiej wprost deklarują własne stanowisko, nie zgadzając się nawet $\mathrm{z}$ korzystnymi dla siebie wynikami spisów ludności: „Białoruska kwestia jest podnoszona z powodu, iż Białorusini jakoby - zgodnie ze statystycznymi danymi - stanowią większość mieszkańców guberni. Biuro GubKoma uważa, że w rzeczywistości Białorusini stanowią jedynie mniejszość" 44 .

Wszystkie wymienione powyżej dowody, opracowane przez homelski oraz witebski oddział komitetów gubernialnych, spotkały się ze sprzeciwem KC KPB, który nie chciał rezygnować z planów powiększenia republiki. Spór rozgorzał $\mathrm{z}$ nową siłą. Bez względu na autorytarny styl sprawowania władzy debata toczyła się na wszystkich płaszczyznach, wraz z zaangażowaniem w nią ludności. Dążąc do uzyskania nowych ziem, rząd BSRR próbował wykorzystać ideologię komunistyczną. Zwracano m.in. uwagę na zagrożenie „rosyjskim szowinizmem”, dostrzegane przez Lenina, gdyż twierdzono, że znów powtarza się sytuacja z czasów caryzmu, kiedy miała miejsce przymusowa rusyfikacja mniejszości narodowych.

Zacytowane powyżej materiały źródłowe w znacznej mierze odzwierciedlają przekonania przeciwników przyłączenia rzeczonych terytoriów do BSRR. Jak widać, najlepiej udokumentowane zostało stanowisko miejscowej biurokracji.

W literaturze przedmiotu istnieją świadectwa wzrostu białoruskiej świadomości narodowej w owym okresie, jednak powinno traktować się je z dystansem. Sytuacja na ziemiach obecnej Białorusi była bardzo skomplikowana. W świadomości mieszkańców dominowała „tutejszość”. Etnogeneza trwała. Na tożsamość ludności determinujący wpływ miała docelowo przeprowadzona polityka, co można zaobserwować, porównując sytuację narodowościową wschodnich województw II RP z obwodami BSRR ${ }^{45}$.

43 Działacze z rosyjskich oddziałów partii komunistycznej nawoływali natomiast do rozgraniczenia według podziału językowego. Zauważalne jest także rozróżnienie spisów ludności, wykorzystywanych przez Rosjan i Białorusinów. Заключение Наркомзема РСФСР по вопросу о расширении границ Белорусской ССР 12 декабря 1923 г., w: Государственные границы беларуси..., т. 1, s. $154-155$.

${ }_{44}$ НАРБ, Ф. 4-п, Оп. 1, Д. 1247, Л. 64-65, Копия.

45 Temat tożsamości Białorusinów na Polesiu Zachodnim został omówiony przez Joannę Gierowską-Kałłaur, „Białorusini” czy „Moskale”? Ludność miejscowa Białej Rusi w świetle raportów 
Jako arbiter w sporze pomiędzy BSRR a zachodnimi guberniami RFSRR wystąpił KC Robotniczo-Chłopskiej Partii (bolszewików). Sytuacja zaczęła wymykać się spod kontroli, ponieważ konflikt toczył się między związkowymi oddziałami tejże partii. Groziło to rozłamem wewnątrz partii, który mógł ją znacznie osłabić. 29 listopada 1923 r. zdecydowano o powiększeniu Białorusi o wszystkie tereny, które „są związane z nią w życiu codziennym pod względem etnograficznym i ekonomiczno-gospodarczym" ${ }^{46}$. Założono, że dotyczy to 9 powiatów guberni witebskiej, 8 powiatów guberni homelskiej oraz 2 powiatów guberni smoleńskiej. Niemniej jednak w celu zmniejszenia napięcia na linii prorosyjscy komuniści probiałoruscy komuniści stworzono komisję ${ }^{47}$, która zajęła się kompleksową analizą sytuacji. W toku rozważań pod uwagę wzięto wyniki powszechnego spisu ludności od $1920 \mathrm{r}$. W niniejszym artykule wspomniano już o tym spisie, gdyż podejmuje on kwestię własnej wiarygodności. Po opracowaniu źródeł statystycznych komisja wydała zgodę na powiększenie Białorusi na wschód, jednocześnie zwracając się do KC z sugestią o pozostawieniu pod jurysdykcją Moskwy (jako stolicy radzieckiej Rosji) powiatów zamieszkanych przeważnie przez Rosjan. W rezultacie na początku $1924 \mathrm{r}^{48}$ do radzieckiej Białorusi zostało dołączonych 15 ujezdów (powiatów) ${ }^{49}$. Decyzja ta spotkała się z poparciem ze strony zebranego zjazdu sowietów ${ }^{50}$. Dzięki zmianom terytorialnym BSRR powiększyła się dwukrotnie, a jej populacja wzrosła z 1,6 mln do 4,2 mln osób ${ }^{51}$.

Prawdopodobnie w znaczącym stopniu do przychylności KC dla Białorusi przyczyniły się rozmaite kwestie o charakterze politycznym, które wcześniej doprowadziły

emisariuszy Straży Kresowej Okręgu Brzesko-Grodzieńskiego, „Studia z Dziejów Rosji i Europy Środkowo-Wschodniej" 48 (2013), s. 44-73 oraz Pavla Ablamskiego, Kwestia narodowościowa na peryferiach Europy Środkowo-Wschodniej. Przypadek Polesia między dwiema wojnami, „Studia z Dziejów Rosji i Europy Środkowo-Wschodniej” 52 (2017), z. 2, s. 57-78.

46 Из Протокола № 49 заседания Политбюро ЦК РКП(б) от 29 ноября 1923 г., w: Государственные границы беларуси..., т. 1, s. 210-211.

$47 \mathrm{Na}$ fakt powołania komisji wskazują dostępne źródła archiwalne, m.in. НАРБ, Ф. 1440, Оп. 3, Д. 478, А.92. Постановление президиума всероссийского ЦИК „об отделении части территории РСФСР к Белорусской ССР” г. Москва от 3 декабря 1923 г., w: Государственные границы беларуси..., т. 1, s. 121-123.

48 Źródłowe dokumenty wskazują na 7 marca 1924 r., Знешняя палітыка Беларусі. зборнік дакументаў і матэрыялац̆, т. 2: 1923-1927 г2., Минск 1999, s. 81-82. Natomiast w literaturze rosyjskojęzycznej można spotkać się z zapisem o lutym $1924 \mathrm{r}$.

49 Początkowo rozpatrywano możliwość dołączenia jedynie 5 ujezdów, a potem inne, co zostało uwzględnione w decyzji Biura Politycznego KC z 19 grudnia 1923 r., Постановление Политбюро Цк РКП(б) о границах Белоруссии г. Москва 29 декабря 1923 г., w: Государственные границы беларуси..., т. 1, s. 240.

50 Zgoda na zmianę granic ze strony Białorusinów została wygłoszona na $\mathrm{V}$ zjeździe białoruskich sowietów. Sprawozdanie z przebiegu tego posiedzenia opublikowano już w 1924 r., Постановления пятого Всебелорусского Съезда Советов, Минск 1924, s. 6-7.

${ }^{51}$ Mniej jawnymi skutkami zmiany były powiększenie przemysłowego potencjału Białorusi dzięki dołączeniu terenów z już istniejącym przemysłem oraz wzmocnienie partyjnej organizacji białoruskiego oddziału partii komunistycznej. 


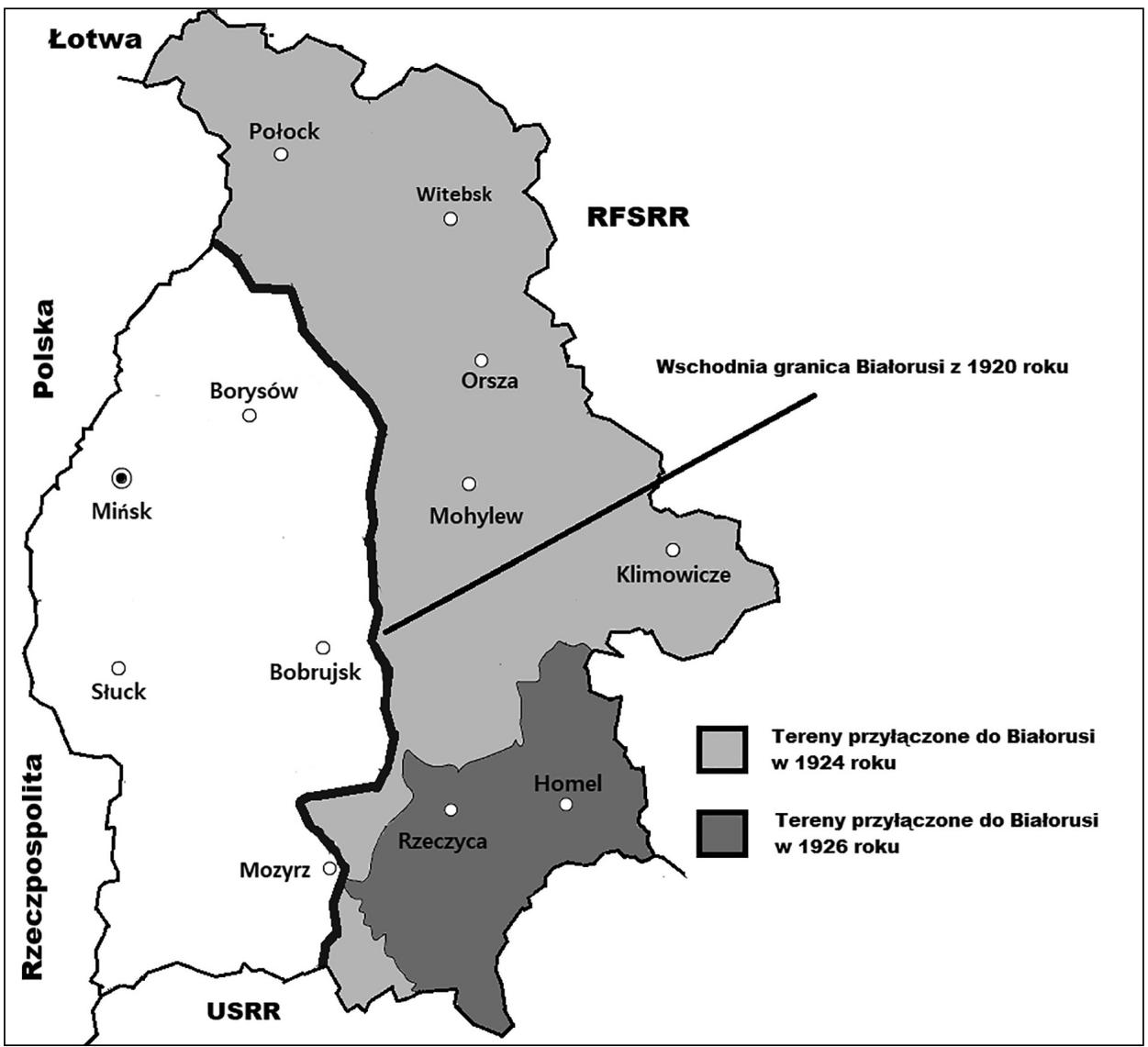

Rys. 1. Zmiany granic BSRR w latach 1920-1926

Opracowanie własne.

do wyodrębnienia jej jako osobnej republiki radzieckiej. Subiektywnych przyczyn tej przychylności struktur organizacyjnych nie uda się obecnie odnaleźć, gdyż część materiałów archiwalnych nadal pozostaje poza zasięgiem historyków. Ponadto można rozważać, czy zachowały się jakiekolwiek świadectwa, które uwzględniają dyskusję na najwyższym szczeblu. Przykładowo na pytanie przedstawiciela północno-zachodniego obwodowego komitetu RPK(b) o przyczyny utworzenia Białorusi jako państwa suwerennego Stalin odpowiedział: „,[doszło do tego] z wielu powodów, których teraz nie można omówić"52.

52 Запись разговора по прямому проводу И.В. Сталина с председателем Северо-западного областного комитета РКП(б) А.Ф. Мясниковым о государственном строительству Белоруссии, w: П.І. Брыгадзін, У.Ф. Ладысеў, Беларусь паміж Усходам і Захадам. Станаўленне дзяржаўнасиі і тэрытарыяльнай иэласнасиі Беларусі (1917-1939 г2.), Мінск 2003, s. $265-266$. 
Po pierwsze, uznanie konieczności stworzenia „przeciwwagi” dla państw nadbałtyckich (w stopniu mniejszym) oraz II RP (w stopniu większym). Narody zamieszkujące wskazane państwa miały już własne doświadczenia w zakresie istnienia $\mathrm{w}$ ramach państwa rosyjskiego. Dlatego też Białoruś, jako podmiot quasi-suwerenny, mogła stać się alternatywnym ośrodkiem przyciągania mniejszości narodowych zamieszkujących wspomniane kraje.

Po drugie, chęć zyskania jak największego wsparcia wśród ludności upadłego Imperium Rosyjskiego, zwłaszcza na niegdysiejszych kresach, która ujawniła swe aspiracje do zdobycia niepodległości po $1918 \mathrm{r}$. Zmuszało to rząd komunistyczny do nadania jak największej liczby przywilejów narodom pozbawionym własnej suwerenności w ramach Imperium Rosyjskiego. Co więcej, wewnątrz partii komunistycznej miał też miejsce konflikt dotyczący narodowego podziału, więc ustępstwa likwidowały zagrożenie wewnątrzpartyjnej konfrontacji na tej płaszczyźnie.

Po trzecie, komunistyczne aspiracje $\mathrm{z}$ lat dwudziestych oraz trzydziestych do „światowej rewolucji” sprzyjały „obdarowaniu” suwerennością narodów, gdyż stanowiło to sposób promowania ideologii komunistycznej na zewnątrz.

W latach dwudziestych oraz trzydziestych wśród elit komunistycznych popularnością cieszyła się koncepcja „unarodowienia”, która zakładała potrzebę stworzenia warunków sprzyjających rozwojowi mniejszości narodowych. Popularność tej koncepcji może wynikać z wojny domowej w Rosji, w której trakcie pozbawione prawa do autonomii mniejszości narodowe stały się głównym zapleczem dla komunistów. Narody wcześniej znajdujące się pod opresją caryzmu zostały uznane za naturalnego sojusznika młodego radzieckiego reżimu. Dlatego też w latach dwudziestych, dzięki leninowskiej polityce narodowościowej, białoruska mniejszość cieszyła się znaczną autonomią polityczną.

\section{Podsumowanie}

W niniejszym artykule zbadane zostały polityczne i etniczno-kulturowe aspekty uzyskania przez Republikę Białorusi terytorialnej suwerenności w ramach instytucjonalnych procesów wewnątrz ZSRR. Cały proces kształtowania się granic Białorusi powinien być uznany za polityczny, gdyż ujawniony obraz wskazuje na dominację tego czynnika. W trakcie analizy źródeł udało się stworzyć zarys dziejów obejmujących lata 1918-1924, do których bezpośrednio odnoszą się kwestie ustanowienia białoruskich granic. Podsumowując podjęty temat, nasuwają się dwa wnioski.

Po pierwsze, zbadany wątek prezentuje niezwykle ciekawy obraz rozwiązania terytorialnego sporu $\mathrm{w}$ ramach systemu $\mathrm{z}$ autorytarnym sposobem sprawowania władzy. Źródła wskazują na nieistotny charakter opinii publicznej, która wykorzystywana była jedynie w celu szantażowania przeciwników oraz stworzenia potrzebnego obrazu w raportach kierowanych do władzy centralnej. Cały proces w uproszczeniu można określić jako spór między Białorusinami komunistami a miejscową 
biurokracją. Dyskusja została zainicjowana przez białoruskie władze komunistyczne, dążące do powiększenia Białorusi poprzez wcielenie do rodzimego państwa wszystkich terenów, które mogły być uznane za zamieszkane przez Białorusinów. Inicjatywa ta natrafiła na opór miejscowej biurokracji partyjnej, gdyż zagrażała dotychczasowemu układowi. Decydującą rolę w sporze odegrała arbitralna decyzja władz centralnych, które stanęły po stronie zwolenników powiększenia Białorusi.

Po drugie, przeanalizowane źródła potwierdziły istotność ideologiczno-politycznego czynnika w procesie kształtowania się granic Republiki Białorusi. Całość opisanych dziejów stanowi jaskrawy przykład pracy biurokratycznego aparatu podporządkowanego hierarchicznemu systemowi, który znajdował się pod presją własnej ideologii. Dlatego też czynnik polityczny został uznany za najistotniejszy, kierował bowiem poczynaniami sprawców. Dzięki przeprowadzonej kwerendzie źródłowej udało się wyszczególnić ważne momenty dotyczące spojrzenia ideologów komunistycznej partii ZSRR na politykę zagraniczną w latach dwudziestych XX w. Natomiast czynnik narodowy w niniejszym przypadku nie wykazał znacznego wpływu, gdyż białoruska świadomość nie stała się poważną determinantą w kwestii kształtowania się granic Białorusi. Owa świadomość - jak wynika z kwerendy - nie istniała. Niski poziom utożsamienia Białorusinów z własną narodowością na początku XX w. pozostawił komunistom szerokie pole do działań, co doprowadziło do zmian granic Białorusi na początku tegoż stulecia.

Bezsprzecznie proces kształtowania się granic między republikami związkowymi w latach dwudziestych był bardzo złożony i wykracza poza zainteresowania jedynie historyków. Instrumentalne traktowanie prawa do samostanowienia oraz tworzenie nowych ośrodków władzy służyły jednemu celowi, a mianowicie światowej rewolucji proletariackiej. Jednak już po przejęciu władzy przez Stalina koncepcja ta została zepchnięta na drugi plan, ustępując miejsca „socjalizmowi w jednym kraju”. Aczkolwiek obecne granice państw postsowieckich przypominają nam o debatach, które toczyły się na początku lat dwudziestych XX w. i zostały dobrze udokumentowane w licznych raportach aparatu biurokratycznego ZSRR.

\section{Political and Ethnic Aspects of the Establishing of Eastern Borders of the Belarusian Republic in 1918-1924}

\section{Abstract}

History proves to us that the shape of state borders is continuously changing. Belarus is one of the few countries with a well-documented process of the statehood establishment - the bureaucratic apparatus of the Soviet Union left many source documents at the disposal of historians. The present article reveals the political aspects of the establishing of the eastern borders of the Belarusian Republic in 1918-1924. An analysis was conducted based on source documents relating to this problem. Due to the close relationship between the establishment of the Belarusian state borders in 1918-1924 and gaining of the statehood, the article also discusses the question of giving sovereignty to the Belarusian nation within the USSR. Special 
attention is paid to the presentation of archival sources, which reveal the process of formation of the eastern state border according to political and ethnic-cultural criteria. In addition, the dispute is presented within the Bolshevik party over the organisation of the state and the right of nations, including Belarusians, to self-determination.

\section{Политико-этнический аспект формирования восточных границ Республики Белоруссия в 1918-1924 гг.}

\section{Аннотация}

История доказывает нам, что очертание государственных границ все время меняется. Беларусь является одним из немногих примеров государств с хорошо документированным процессом формирования государственности- бюрократический аппарат Советского Союза оставил после себя много источников. В рамках данной статьи было решено раскрыть политический аспект формирования белорусских границ в 1918-1924 гг. Анализ проводился на основании обработки документальных источников, касающихся исследуемого явления. Из-за тесной связи вопроса формирования белорусских границ в 1918-1924 гг. с обретением Белоруссией государственности в статье были также затронута проблематика предоставления суверенитета белорусскому народу в рамках СССР. Особенное внимание в тексте было обращено на презентацию архивных источников, которые раскрыли процесс формирования восточной государственной границы на основе политических, а также этническо-культурных критериев. Кроме того, был представлен спор внутри большевистской партии, касающийся организации государства и вопроса права наций, включая белорусов, на самоопределение.

\section{Bibliografia}

\section{Źródła}

Narodowe Archiwum Republiki Białoruś (НАРБ)

Ф. 4-п, Оп. 1, Д. 1247, Л. 64-65, Копия; Л. 66-73, Копия; Л. 1-7; Д. 683, Л. 10-14, Копия; Д. 2479, Л. 61-64, Копия

Административно-территориальное устройство БССР: справочник. В 2-х томах, т. 1: 1917-1941 г2., Минск 1985.

Государственные границы беларуси. Сборник документов и материалов в двух томах, t. 1, Минск 2012.

Знешняя палітыка Беларусі. зборнік дакументаў і матэрыялаў, т. 2: 1923-1927 г2., Мінск 1999.

Постановления пятого Всебелорусского Съезда Советов, Минск 1924.

Седьмая (Апрельская) Всероссийская конферениия РСДРП(б). Стенографический отчет, Москва 1958.

\section{Opracowania}

Ablamski P., Kwestia narodowościowa na peryferiach Europy Środkowo-Wschodniej. Przypadek Polesia między dwiema wojnami, „Studia z Dziejów Rosji i Europy Środkowo-Wschodniej” 52 (2017). 
Borzęcki J., The Soviet-Polish Peace of 1921 and the Creation of Interwar Europe, New Haven 2008.

Ciesielski S., Kresy Wschodnie II Rzeczypospolitej i problemy identyfikacji narodowej, w: Przemiany narodowościowe na Kresach Wschodnich II Rzeczypospolitej, red. S. Ciesielski, Toruń 2003, s. 9-51.

Gierowska-Kałłaur J., „Białorusini” czy „Moskale”? Ludność miejscowa Białej Rusi w świetle raportów emisariuszy Straży Kresowej Okręgu Brzesko-Grodzieńskiego, „Studia z Dziejów Rosji i Europy Środkowo-Wschodniej" 48 (2013), s. 44-73.

Głogowska H., Białoruś 1914-1929. Kultura pod presja polityki, Białystok 1996.

Kipel V., Kipel Z., Byelorussian Statehood. Reader and Bibliography, Michigan 1988.

Marples D.R., Belarus. A Denationalized Nation, Abingdon 1999.

Michaluk D., Białoruska Republika Ludowa 1918-1920. U podstaw białoruskiej państwowości, Toruń 2010.

Michaluk D., Białoruska Republika Ludowa między Wschodem a Zachodem (1918-1919), „Studia Białorutenistyczne" 3 (2009), s. 63-101.

Mironowicz E., Tokć, S., Radzik, R., Zmiana struktury narodowościowej na pograniczu polsko-białoruskim w XX wieku, Białystok 2005.

Radzik R., Między zbiorowościa etniczna a wspólnota narodowa. Białorusini na tle przemian narodowych w Europie Środkowo-Wschodniej XIX stulecia, Lublin 2000.

Snyder T., The Reconstruction of Nations. Poland, Ukraine, Lithuania, Belarus, 1569-1999, Oxford 2003.

Wróbel P., Kształtowanie się białoruskiej świadomości narodowej a Polska, Warszawa 1990.

Басалай А., Развитие наций и их взаимоотношений в СССР, Москва 1998.

Белявина В.Н., Беларусь в годы Первой мировой войны, Минск 2013.

Борисёнок Ю.А., Белорусско-российское пограничве в 1918-1944 годах, „Вопросы истории” (2004), nr 12.

Брыгадзін П.І., Ладысеў У.Ф., Беларусь паміж Усходам і Захадам. Станаўленне дзяржаўнасиі і тэрытарыяльнай иэласнасиі Беларусі (1917-1939 г2.). Мінск 2003.

Волкава В.В., Адміністрацыйна-тэрытарыяльнае ўладкаванне акупаванай тэрыторыі Беларусі ў гады Першай сусветнай вайны (кастрычнік 1915 г. - люты 1918 г.), „Беларускі Гістарычны Часопіс" (2017), № 10.

Волкава В.В., Пашпартная сістэма зоны Обер Ост у гады Першай сусветнай вайны, „Беларускі гістарычны часопіс” (2015), № 3.

Гринблат М.Я., Белорусы. Очерки происхождения и этнической истории, Москва 1968.

Коршук У.К., Платонаў Р.П., Раманоўскі І.Ф., Фалей Я.С., Беларусізащья. 1920-я гады. Дакументы і матэрыялы, Минск 2001.

Лазько Р.Р., Кротаў А.М., Мязга М.М., Беларусь у еўрапейскай палітыиы,, 1918-1925 г2. Нарысы, Гомель 2003.

Требов О.В., Как большевики делили гомельскую губернию между Россией и Белоруссией, „Родина” (2003), № 8.

Хомич С., Территория и государственные границы Беларуси в ХХ веке. От незавершенной этнической самоидентификации и внешнеполитического произвола к современному status quo, Минск 2011.

Ціхаміраў А.В., Беларусь у сістэме міжнародных адносін перыяду пасляваеннага ўладкавання Еўропь і польска-савецкай вайны (1918-1921г2.), Мінск 2003.

Штыхов Г.В., Археолагі дапаўняюиь тетапісиаў, Мінск 2009. 
Stanisław Boridczenko, absolwent Uniwersytetu Jagiellońskiego, doktorant Instytutu Historii Uniwersytetu Szczecińskiego, przygotowuje rozprawę doktorską poświęconą obrazowi stosunków polsko-rosyjskich w literaturze edukacyjnej Imperium Rosyjskiego. Zainteresowania badawcze: proces kształtowania się granic państw Europy Środkowo-Wschodniej po I wojnie światowej, narracja historyczna w podręcznikach szkolnych poszczególnych państw wschodniosłowiańskich wobec „sprawy polskiej”, historia historiografii Imperium Rosyjskiego (esanius@gmail.com).

Stanisław Boridczenko, a graduate of the Jagiellonian University, PhD student at the Institute of History of the University of Szczecin, where he is currently writing a dissertation on the topic of portrayal of Polish-Russian relations in the educational literature of the Russian Empire. Research interests: the process of border shaping in Central and Eastern Europe after WWI, historical narrative in East Slavic school textbooks on the "Polish question", history of historiography of the Russian Empire (esanius@gmail.com). 